\title{
EFFECT OF GENDER AND EDUCATIONAL QUALIFICATION ON ADMINISTRATIVE EFFECTIVENESS OF LIBRARIANS IN FEDERAL UNIVERSITIES IN SOUTH-SOUTH NIGERIA
}

\author{
${ }^{* 1}$ Offem, C. O. \& ${ }^{2}$ Otun, M. O. \\ ${ }^{1 \& 2}$ Department of Library and Information Science, University of Calabar, Nigeria \\ *Corresponding Author Email: offemco@uncial.edu.ng, otmum6k@unical.edu.ng Phone: +2348038067590
}

\begin{abstract}
The study was carried out to determine the effect of gender and educational qualification on the administrative effectiveness of librarians in federal universities in South-South Nigeria. The study adopted the non-probability sampling technique together with the ex-post facto research design which implemented the purposive and accidental sampling technique in selecting the population. A total of two hundred and thirty-one (231) respondents were selected from six federal university libraries which comprised one hundred and seven professional (107) librarians and one hundred and twenty-four (124) Para-professionals. Data were elicited through a questionnaire. Data were analyzed using both descriptive and inferential statistics (independent t-test, one-way analysis of variance and multiple regression analysis. The research questions were answered and the hypotheses were tested at 0.05 levels of significance. Results show that there is a positive correlation between educational qualification and administrative effectiveness of librarians in the South-South universities of Nigeria. Secondly, a significant result was obtained for gender as a predictor of administrative effectiveness of librarians. The study, therefore, recommends that employers of librarians should allow them to improve themselves via acquiring postgraduate qualifications such as a master's degree and $\mathrm{PhD}$ as this will go a long way to add value to them and improved their skills.
\end{abstract}

Keywords: Gender, Librarians, Administrative effectiveness, Educational qualification, Para-professionals, Federal universities, SouthSouth Nigeria

LICENSE: This work by Open Journals Nigeria is licensed and published under the Creative Commons Attribution License 4.0 International License, which permits unrestricted use, distribution, and reproduction in any medium, provided this article is duly cited.

COPYRIGHT: The Author(s) completely retain the copyright of this published article.

OPEN ACCESS: The Author(s) approves that this article remains permanently online in the open access (OA) model

QA: This Article is published in line with "COPE (Committee on Publication Ethics) and PIE (Publication Integrity \& Ethics)". 


\section{INTRODUCTION}

Gender according to the Webster Comprehensive dictionary of the English language define gender sex. Historically and indeed philosophically speaking, there has been the difference of opinion as to the role ability of men and women. Human existence from its earliest times emphasized the male-female dichotomy, as scholarship in various fields of intellectual endeavor shows. In Judea, Christian world view both sexes as created equal, but the female is subsumed in the male as a result of the fall because an aspect of the curse-stipulates that "Thy desire shall be to thy husband, he shall rule thee" (Gen. 3:16).

Gender theories, from classical to the modern age, maintain male power and female subordination. Plato in his republic feels men and women have equal opportunities and can attain the same heights given the same opportunity. It has been established by some researchers that males perform significantly better in many spheres of life than the female.

However, some authors argued the existence of any clear difference. According to Lawal (1983) "the gender factor in library services sometimes makes itself obvious in the logic that truly there are a lot of women in the practice but the expertise is presently dominated by men", he said, in recruitment, one needs to be careful choosing women to be recruited, should there be spinsters or married women, spinsters sometimes would marry and shift base with their husbands thereby leaving the library services groping for a replacement while married women on the other hand would continue to obtain maternity leave and other sick leave which eventually may affect productivity.

\section{STATEMENT OF PROBLEM}

The Academic library is being described as the "heart" of a university and one of the most essential academic units of the university; the laws establishing university institutions in Nigeria are terse on the duties, functions and responsibilities of the librarian. The librarian main duties and responsibilities are to provide library resources and services.

The library staff is an indispensable part of library resources. They constitute the human resource that coordinate, plan and organize the resources to achieve the goals of the library. By virtue of the complex nature of human beings, it takes good management skills and leadership qualities to successfully coordinate them to achieve organizational or library goals at the command of the librarian as the team leader.

But despite of all the educational prowess of the librarian; experience, leadership style, etc. one observes inefficiency on the part of the staff towards the library services and their attitude to users. It is this preliminary observation of the ineffectiveness of the university of Calabar library staff and the leadership of the librarian that provoked this study, to investigating if gender could be responsible for administrative effectiveness, or if educational qualification could be the problem or if both gender and educational qualification could be responsible for administrative effectiveness.

\section{RESEARCH QUESTIONS}

The research work seeks to provide answers to the following questions:

1. What is the influence of educational qualification on administrative effectiveness of librarians? 
2. What is the influence of gender on administrative effectiveness of librarians?

\section{RESEARCH HYPOTHESES}

$\mathrm{Ho}_{1}$ : There is no significant relationship between educational qualification and administrative effectiveness of librarians.

$\mathrm{Ho}_{2}$ : There is no significant relationship between gender and administrative effectiveness of librarians.

\section{LITERATURE REVIEW}

Many researchers' results had given evidence that sex-stereotype was not a criterion in administration. However, sex was a factor of personal background because people seemed to relate it towards jobs. According to Madunagu (2010) Gender is defined as a widely shared ideas and expectations of how women and men should behave in various situations. These ideas and role expectations reflect and influence the different roles, social status, economic and administrative power of women and men in the society. Fadekemi and Isaac (2011) reveals growing skepticism with the strength of gender typecast of men as instrumented, bureaucratic and competitive being and women as nurturing, relational and collaborative beings respectively. Saduwa (2011) maintained that gender has its own advantages and disadvantages for management effectiveness of administrators, but there is more emphasis on their capabilities. This capability may be gained through further training, higher education or even from years of experience on the job. Olorunsola (2012) tried to find out whether the administrative staff job performances were related to their sexual characteristics. It was revealed that there was a significant relationship between the job performance of female and male administrative staff in the universities. The study recommended that more enablement should be given to both female and male administrators to perform by organizing seminars, conferences, and workshops both within and outside Nigeria. Anumaka and Ssemugenyi (2013) examined the influence of gender on staff or employee productivity in selected private universities in Kampala city, Uganda. It was found that there was a slight difference in work productivity between male and female.

Aguh, (2003) carried out a study to investigate principals, personal characteristics and administration of secondary schools. The focus was to ascertain the extent to which personal factors of the principals such as gender, age, qualification and experience could influence their administration. The descriptive survey was the design of the study. Five research questions and five hypotheses guided the study. The population of the study comprised all 245 principals in the state. A sample of 120 principals randomly selected from the population. Data were gathered from the sampled respondents through a Likert type rating scale titled "Principal Personal Characteristics Questionnaire (PPCQ). The instrument's reliability was determined using Cronbach alpha and it was 0.76 . To answer the research questions means and standard deviations was used, while t-test and ANOVA were used to test the hypotheses at 0.05 levels of significance. The results indicated that there was no significant difference between female and male principals in their administration of secondary schools in Rivers State. The result further indicated that female principals tend to be very strict than their male counterpart in demanding attendance and devotion to duty on the part of teachers to demystify the general notion that they are the weaker sex. It was also found that female principals were less committed to their job than the male principals in the school since most of them as mothers and housewives are duty bound to 
care for their husbands, children and family. Therefore, they are left with little or no time to follow up on official matters outside office hours. Similarly for the male principals, it was found that they do not make time allowance for staff attendance since other business commitments outside the school unrelated to their official assignment always keep them out, hence they are not also too committed like their female counterparts in the discipline of staff. This observation goes to show that being male or female is irrelevant, what matters is being effective at what ones job requires him or her to do This study is related to the present study since both of them investigated the relationship between personal variables of administrators and their administrative effectiveness. They differed in design employed, study area, population, sample and sampling technique and tools for data analysis.

A study by Wagbara (2007) determined the influence of gender factors and the administrative performance of principals of secondary schools. The descriptive survey design was adopted and four research questions and four hypotheses were designed and tested at 0.05 level of significance. The population of the study was 245 comprising vice principals of public secondary schools in Rivers State. A sample of 105 vice principals drawn from a population of principals in that state using simple random sampling technique was used as respondents. A 40-item questionnaire titled "gender factors and administrative performance of principals of secondary schools in River States" with 0.75 reliability co-efficient obtained in trial testing was the instrument used for data collection in the study. The research questions were answered with the use of simple percentage while the hypotheses were tested using the t-test. The findings revealed among others that male and female principals differed significantly in the discharge of their supervisory roles while male and female principals did not significantly differ in their administrative capabilities in the management of secondary schools in Rivers State. This finding also implies that what matters is the capabilities of these officers and not whether they are male or female. The relationship of the study to the present study is that, both studies investigated the influence of gender, but they differed in design, population, and statistical tools for data analysis.

Olaleye (2001) study was to determine the influence of gender differences of principals in their effectiveness in school community relations. The research study was based on stereotyped assumption that female principals do not have what it takes to perform their job effectively unlike their male counterparts particularly in school management. The descriptive survey design was adopted. The population of the study comprised the majority of principals and teachers in public secondary schools in Osun State. Four research questions and four hypotheses aided the study. A sample of one thousand (1000) teachers made up of 500 male teachers and 500 female assessed the principals. The Teacher Observation Questionnaires (TOQ) with a reliability coefficient of 0.78 established using cronbach alpha was used to assess the level of the principal's performance in the establishment of school - community relations. The research findings revealed that the gender of the principals had no impact on their ability to establish good community relations. Both female and male principals perform equally well and employed similar leadership behavior in this regard. The study is similar with the present study as both examined the influence of gender on administrators' job performance, but differed in the design, population and effectiveness or job performance indices examined while the study of Olaleye (2001) examined administrators (School principal) performance in one managerial area (establishment of school community relations), the present study assessed administrative effectiveness in more than three indices. 
Akiri and Ugborugbo (2008) conducted a study on examination of gender's influence on teacher productivity in secondary school in Delta State, Nigeria. The study was to examine the influence of gender on the productivity of teachers. The study was a descriptive survey that employed an ex post facto design. Five research questions aided the study. The population of the study was 11, 499 teachers who are employees under Delta State Post Primary Education Board as at 2004/2005 academic session. A sample of 979 teachers comprising (400) males and (519) females was drawn from the population using a stratified random sampling technique which involved multi-level sampling procedure. The Instruments for data collection were two questionnaires namely: Teachers Effectiveness Questionnaire 1 (TEQ1) with 22 items to evaluate the teaching effectiveness of teachers, and Teachers Effectiveness Questionnaire II (TEQII) also with 22 items for students to evaluate teachers' classroom effectiveness, percentages, t-test, z-test and single factor analysis of variance were used to analyze the data. The result demonstrated that the performance of teachers was significantly influenced by location by weighted means of 72.10, 70.92, and 70.35 for urban, semi-urban and rural schools respectively. The results also revealed that there was a significant difference in the mean productivity of female and male teachers. The male teachers were generally more productive than their female counterparts in rural areas, while the female performs better in urban schools than their male teachers. The study suggested that school managers should put gender into thought when posting teachers to various locations, that is, efforts should be made as possible to post female teachers to urban and semi-urban schools while more males may be retained in rural schools with attractive incentives. Furthermore, in-service training, projected to enhance job performance should be organized regularly, especially for female teachers in the first five years of employment. Efforts should also be made to return experienced female teachers in secondary schools, while more males should be encouraged to teach in secondary. From the study above, it can be deduced that the difference in performance by the different gender could have been moderated by the different locations. This further implies that other factors other than being made or the female may act concomitantly to affect or influence the administrative effectiveness of librarians.

Finally, more males should be encouraged to teach in secondary schools. The study is related to the present study, which investigated gender variation, but differed in focus and design. The study focused on the productivity of teachers while the present study focused on administrative effectiveness of librarians. A study by Uko (2002) examined the effect of leadership styles and gender on administrative effectiveness of principals in secondary schools. The design of the study was the descriptive survey. Three research questions aided the study. The population of the study comprised of principals, vice principals and teachers of public secondary schools in Cross River State. A sample size of 1000 teachers and 200 principals and vice principals were randomly selected as respondents from 100 secondary schools in Cross River State, two instruments, namely Principals Leadership Style Questionnaire (PLSQ) and Principals Performance Effective Questionnaire (PPEQ). The reliability coefficients of the instruments were determined by using the Cronbach alpha method which was 0.78 and 0.65 respectively. Using Chi-square to analyze the data in the influence of gender in principals' leadership styles, it was found that women scored low on human relations because they were seen to be more officious in their relationship with people, including staff, students and visitors while men were seen to be clever to camouflage their emotional problems to the extent that they could easily handle difficult situations. The findings revealed that men are better school administrators. This study relates to the 
present study because both examined gender variables, but differed on the population surveyed and the statistical tool used for analysis.

A study by Okpe (2010) investigated the effect of demographic variables and school climate on principals' job performance in public secondary schools. The study made use of ex-post factor research design. The sample consisted of 298 principals randomly drawn from public secondary schools in Southeast Nigeria. Three research instruments were developed and used by the researcher for data collection. The instruments are Demographic Data of Principals Questionnaire (DDPQ) which sought the personal data of the principals.

The School Climate Descriptive questionnaire (SCDQ), with twenty-five (25) items which sought information on school climate and the principal Job performance description questionnaire (PJPDQ) with sixty-two (62) items. The reliability coefficients of the instruments using Cronbach alpha were: 0.96 for SCDQ, and 0.97 for PJPDQ. The data obtained were analyzed using mean, standard deviation, ANOVA, and multiple regressions. The major findings of the study are professional qualifications, experience and gender significantly influenced principals' job performance. Professional qualification significantly influenced principals' job performance. School climate significantly influenced principals' performance. The study concluded that school principals required professional qualifications and that principal should support and encourage a positive school climate. The study is similar to the present study because both investigated the influence of demographic variables and performance using the similar research design, but differed in terms of the study area, population and focus. The study was carried out in the Southeast, Nigeria while the present study was carried out in south-south, Nigeria. The study surveyed principals' performance while the present study survey university librarian's administrative effectiveness.

The study by Asif, Khan, Raozan,and Tahumulla (2012) was designed to estimate and compare the performance of female and male institutional Heads appointed in the secondary schools of DeraIsmall Khan which is a southern district of Khyber Paktatnun Khwa province of Pakistan. The population for the study comprised all the teachers working in public secondary schools in the district for being the best judges of the performance of their heads, to estimate and compare the performance of the male and female institutional heads. A total of twenty public schools, ten males and ten females were selected randomly whereas six teachers from each school were taken using a simple random sample for data collection thus consisted of one hundred and twenty (120), that is, sixty male and sixty female teachers working in the respective secondary schools. Structured questionnaires were used as instrument for data collection, which was built on a five-point Likert Scale ranging from 'excellent' to very poor'. The instrument consisted of thirty-five items related to the problem. Cronbach alpha was used for checking the reliability of the measuring scale which remained at 0.815 . The researcher administered the questionnaire with the help of coresearchers, collected data were entered into the SPSS (Statistical Package for Social Sciences) for statistical analysis, and independent sample t-test was applied for comparison of the performance of female and male institutional heads. According to Asif, Khan, Raozan,and Tahumulla (2012) the study revealed that female institutional heads exhibit to be relatively better administrators showing intense interest in institutional administration, keeping a cordial relationship with staff and motivating their team hard work $\mathrm{x}=3.97, \mathrm{SD}=0.850$ for female and $3.04, \mathrm{SD}=1.428$ for male., $t=3.002>t-$ value 1.960. Results of the independent sampled $t$-test for evaluating the conscientious of male and female institutional heads in mentoring the discipline within their institution produced mean score for the 
female administrator i.e. 3.43 which proved to be greater than that of male administrator i.e 2.62 with SD of 1.406 and 1.472 respectively for female and male. The calculated t-value -2.124 was found greater than tabulated t-value 1.960.

In many developing countries female instructional heads get their positions either by chance or by clear career planning or aspiration into institutional headship. Major factors that affect the difference between male and female working as administrators are their family responsibilities and marital status (Lad's 2000). A study conducted in Nambia concluded that woman institutional heads are more effective than their male counterparts, because they are well organized, caring and at establishing relations with others and good at communicating, although these qualities contradict their nature. This implies that administrative effectiveness may or may not be related to the officer being either male or female. Other factors may underlie their functions at any point in time. Amzat and Al-Ani (2011) posited that basic institution's female heads are more successful than male administrators in getting an institutional mission and vision, developing knowledge and institutional environment, participation of the community and administration of institutional building. On the other hand, same study indicates that male heads are more competent to hold up the planning and development overall, analyses revealed that female officers proved to be more painstaking in the maintenance of the school discipline than their male counterpart. This observation supports the findings of Daresh and Male (2000) who reported that female principals are more effective and efficient in school administration because they extend their motherhood roles to the school environment. On the finding that male heads are more competent than females to hold up the planning and development, this finds support in Uko's (2002) observation that male's exposure to varied problem-solving situations account for their administrative effectiveness. This study relates to the present study since it examined gender differences in institutional administration, but different in terms of research design, population and area of study.

\section{EDUCATIONAL QUALIFICATION AND ADMINISTRATIVE EFFECTIVENESS}

The changing role of academic librarians as knowledge managers, emphasizes the need to constantly update or acquire new skills and knowledge to remain relevant in today's library environment. Dadzie (2005) asserted that for information to be maximally usable, it must have the following qualities, timeliness, accuracy, relevancy, currency, completeness, clarity and cost-effectiveness. Libraries and librarians are expected to provide good quality services to her users; hence the librarian's knowledge of information resources plays a vital role of the universities, colleges of education and polytechnic education in this information era.

At present there are five district programs to train librarians at various levels. They include certificate, diploma, Bachelors' degree, master's degree and the doctoral degree in Library science. Hence Librarians at the federal universities possess either of these degrees and this can exert influence on their administrative effectiveness Lawal (2006) observed that, the degree qualification differs in content and context for example, BLS compared with a whole range of other first degrees that are not in library science shows that the curriculum of the library school include the demand for skills of the individual expected for recruitment. Furthermore, Lawal (2006) asserted that, graduate entry into the profession usually begins with a master's degree in library science (MLS) qualification. This level of education entitles the individual on graduation to be described as a professional who could be recruited into the library as a first 
professional and this is the global requirement, beyond these qualifications, the individual librarian now specializes in acquiring additional professional qualifications.

From the assertion of (Lawal, 2006) above, it could be deduced that the first educational level for recruitment into librarianship that could qualify one to be described as a professional on his job is a master's degree in library science (MLS), this means that level of education is important in explaining librarians' administrative effectiveness. Kumar (2009) noted that preservation and access to knowledge and information is the mandate of academic libraries alongside supporting the mission of their parent institutions. Subsequently, the changing job of scholarly bookkeepers as information administrators, underlines the need to continually refresh and procures new abilities and information to stay significant in the present library climate.

This could be the explanation of Elem (2013) where he asserted that the higher a librarian, educational attainment, the more inventive he/she becomes in help conveyance. This backings Bello (2005) who thinks that the curator requires great administration and backing in the arrangement of work instruments and favorable work space, accessibility of materials and openness to materials. This implies that for the curator to work viably the person ought to have the option to put together and facilitate both human and material assets, the individual in question should be learned and information comes from instructive involvement with the field of data and library science and other important managerial courses.

Obi, (2020) put it that the leader must motivate the work force "that a motivated workforce is a productive and most reliable source of strength". This implies that the librarian as a leader of the library team, must be able to add "motivation" among other factors to gain administrative effectiveness. Edem (2004), advised that if quality services are to be provided, personal characteristics of the numerous users of academic libraries should be given adequate attention. It is important to note that educational qualification is the personal characteristics that is not fixed, it can be improved upon unlike gender. Therefore, individuals' personal characteristics play out in the manner in which they carry about administrative duties and as such, the outcome of the influence can be positive or negative.

Allen (2015) recommended that managers of education industries and school administrators attend conferences, seminars, and workshops, in order to improve their skills in school management and supervision, among other things, in a study titled Effective school management and supervision: imperative for quality education service delivery. As an institution administrator has set objectives to accomplish in like manner the librarian has objectives to accomplish as well. Therefore, to successfully or effectively accomplish these set objectives, the person in question has to team work with other staff within the school system and able to inspire them to work cooperatively with him so as to achieve the educational objectives.

In like vein Sidho (2002) averred those certain principles are important for the achievement of school objectives. They include; consistent with the philosophy of education, democratic approach, optimum contribution by all respects for individuals, due importance to different programs and an optimistic outlook. To develop the capacity to function effectively, the librarian for instance needs to be abreast of some theories and principles in educational administration, such as; leadership theories, decision-making theories, communication theories, conflict theories, motivational theories and human relation theories. It is only through educational experiences that these skills would 
be acquired. If these skills are acquired and are well applied in the job situation, the librarian may be more effective administratively and otherwise

Ogunyimi (2005) observed that good qualification is a necessary prerequisite for effective school administration and supervision. Khan (2001) study showed that heads with higher professional qualifications are more efficient. Contrary to Khan's findings above, Ogbaji and Oti (2006) posited that professional qualification of administrators (principals) has no impact on their job performance. To the authors on the job experience is a more important variable in the job performance of school administrators and supervisors than professional qualification.

Aguh (2003) in a study discovered that educational qualification was not a significant factor in the principals' administration of schools. The study's findings showed that principals without postgraduate qualifications performed as highly as those with postgraduate qualifications in the administration of secondary schools. Ebong (2003) conducted research to examine the association between years of education and worker productivity in both the private and public education sectors in Nigeria's south-south region in South-South Nigeria. The sample of the study was 1000 employees randomly selected. The instruments for data collection were questionnaire and oral interview. Mean, standard deviation and Pearson product moment correlation were statistical tool for data analysis. The findings showed that people with higher degrees achieved set goals because they understood the job description as experts. The author reasoned that, people exposed to many years of professional training engage in productive behaviors such as punctuality they execute duties and are creative as they have alternative solutions in crisis situations, hence enhance productivity in their different responsibilities. The study is related to the present study because both investigated the correlation between qualification and workers (e.g., Librarian) productivity or effectiveness, but they differed in design, and statistical tool used.

Okendu (2009) evaluated the impact of professional qualifications on secondary school principals' administrative effectiveness. A descriptive survey research method was used in this study. The study was led by three research topics and three null hypotheses. The population of the study was 52 principals of government owned secondary schools, which comprised of 24 principals for both junior and senior secondary schools in Ikwere and 28 junior and senior secondary school principals from Emuoha Local Government Area. A sample of 42 principals from the population was drawn using random sampling techniques. A 25 -items, structured questionnaire was the instrument for collecting data. The respondents were required to react to statements on aspects of professional development, instructional supervision, interpersonal relations with teachers and decision -making. The findings revealed that principals' instructional development has a substantial association with teacher supervision of instruction, and school organizational development has a strong relationship with teacher supervision of instruction. With personal growth/development has no significant association with principals' inter-personal ties with teachers, while school organizational development has a substantial relationship with principals' decision-making in the school. The two studies are similar since they both looked at administrative effectiveness and qualification, though not in the same task areas (that the indices for assessing administrative effectiveness). While the previous study used a descriptive survey, the current study used an ex-post -facto design. They also employed different statistical tools. The current study employed ANOVA, independent t-tests, and multiple regression analyses instead of the previous study's Pearson product moment correlation coefficient. 
Adenuga (2008) conducted another study to examine the combined and individual contributions of the personal variables of sex, age, teaching experience, and qualification to the variance of secondary school principals' administrative effectiveness and efficiency in Ogun State, Nigeria. The descriptive correlational survey design was used in this investigation. The study was led by five research questions. The study's participants were all principals of government-run secondary schools in Ogun State. The study included a random sample of 300 principals from four divisions across the state. The leader's personal variable questionnaire (LPVQ) made up of 10-items that sought the demographic information of the respondents and present effectiveness scale (PES) consisting 50 items that sought information on the effectiveness and efficiency of personnel were used to collect data for the study. The (6) instruments were duly validated and trial tested and yielded reliability coefficients of 0.76 and 0.85 for (LPVQ and PES) respectively using cronbach alpha method. The multiple regression and analysis of variance (ANOVA) were used to analyze the data.

Findings from the study revealed a low, positive correlation $(R-0.20)$ exists between the four predictor variables (age, gender, experience and qualification) and principals' administrative effectiveness. The regression analysis was not significant at 0.05 level as shown by the ANOVA test $(F=1.527, p>0.05)$. The $R^{2}$ value of 0.04 showed that the 4 variables when combined accounted for only $4 \%$ of the variance observed in the principal's effectiveness. Other factors not included in the study accounted for the other variants (96\%). Hence the four predictor variables jointly and insignificantly contributed $4 \%$ of the variance in the principal's personal effectiveness. The outcome of the study, according to the researcher might be as a result of the fact that for anybody to be the head of a school, he or she must have been matured both in age and in qualification coupled with his experience in life. The gender of the principal might not have a well pronounced influence(s) on his achievement most especially in this contemporary world when women have been known to achieve excellence in different field of callings. The researcher recommended that principals' personal variables of experience and qualification should be considered in appointing teachers to position of authorities in schools. This study relates to the present study area, both are interested in demographic variables as predictor of the principal's administrative performance, but differed in the area of the study and population. In the present study, and population. In the present study, the relationship between these variables and leadership styles was examined.

The influence of teacher qualification on the performance of Senior secondary school students in Physics was investigated by Owolabi and Adedayo (2012). The goal of the study was to see if the educational status of the teachers had any bearing on the students' performance in Physics. The study's sample included 100 senior secondary school physics students from Ekiti State, as well as the teachers who prepared and presented the students at each school for the 2009/2010 West African School Certificate Examination. Each school's year-end performance report was combined with the biodata of their respective physics teachers. At a significance threshold of 0.05 , the hypotheses were tested. Inferential statistics were used to analyze the data. Students taught by teachers with greater qualifications did better than students taught by teachers with lower qualifications, according to the findings. It was also discovered that when pupils were taught by expert professors, they did higher in Physics. The findings of this study suggest that efficacy is a function of greater educational qualifications, and the same can be said for the administrative effectiveness of librarians. 


\section{METHODOLOGY}

For this study, an ex-post facto research design was used. The technique for unlikely sampling with purposeful and accidental sampling was used. Only six (6) federal universities were selected for this study from state and private universities. The accidental sampling was adopted as the researcher gave the instrument to the librarians only. This method made no provision for estimation of the representativeness of the sample. The sample size was made up of two hundred and thirty-one (231) professional and para-professional librarians of six (6) federal universities under study. One hundred and twenty-four (124) para-professionals drawn from the following universities under investigation - Bayelsa 12A, Benin 17A/10B, Calabar 18A/25B, Port-Harcourt. 28A/30B, University of petroleum resources Efurum 9A/6B and Uyo 23A/53B. The population of Librarians was denoted by A while that of paraprofessionals was denoted B.

\section{RESULTS}

Table 1 below shows the distribution of the population, according to professional ( $\mathrm{N}=107)$ and Para-professional staff $(\mathrm{N}=124)$ in the apex institutions in the South-South Nigeria. Table 2 shows the distribution of gender that make up the population. The population comprised of $55.8 \%$ male staff $(\mathrm{N}=129)$ and $44.2 \%$ female staff $(\mathrm{N}=102)$ of the total population which is 231 .

Table 1: Distribution of population and sample of the study

\begin{tabular}{llll}
\hline S/N & Name of institutions & $\begin{array}{l}\text { Number } \\
\text { professionals }\end{array}$ & $\begin{array}{l}\text { of } \\
\text { professionals }\end{array}$ \\
\hline 1 & University of Bayelsa & 12 & 0 \\
2 & University of Benin & 17 & 10 \\
3 & University of Calabar & 18 & 25 \\
4 & University of Port Harcourt & 28 & 30 \\
& & & 6 \\
5 & University of Petroleum & Resources- & \\
& Efurum & 9 & 53 \\
6 & University of Uyo & 23 & $\mathbf{1 2 4}$ \\
\hline
\end{tabular}


Table 2: General description of data $(\mathrm{N}=231)$

\begin{tabular}{lll}
\hline Gender & Frequency & Percent \\
\hline Male & & 55.8 \\
Female & 129 & 44.2 \\
Total & 102 & 100.0 \\
\hline
\end{tabular}

\section{TEST OF HYPOTHESIS ONE}

The tables below show one-way ANOVA test for the correlation between educational qualification and administrative effectiveness of librarians $(\mathrm{N}=231)$

Table 3: Sizes, Means and SD of respondents based on the levels of their ages.

\begin{tabular}{|c|c|c|c|c|}
\hline & $\begin{array}{l}\text { Educ. } \\
\text { Qualification }\end{array}$ & $\mathbf{N}$ & MEAN & $\begin{array}{l}\text { STD } \\
\text { DEVIATION }\end{array}$ \\
\hline \multirow{3}{*}{ LEADERSHIP ROLE } & 1 & 47 & 16.8298 & 1.89185 \\
\hline & 2 & 124 & 19.25 & 0.67021 \\
\hline & 3 & 60 & 19.2167 & 0.73857 \\
\hline \multirow{6}{*}{ STAFF MOTIVATION } & Total & 231 & 18.7489 & 1.42865 \\
\hline & 1 & 47 & 18.0213 & 1.60826 \\
\hline & 2 & 124 & 17.8629 & 0.60263 \\
\hline & 3 & 60 & 19.7833 & 0.41545 \\
\hline & Total & 231 & 18.3939 & 1.19991 \\
\hline & 1 & 47 & 15.8085 & 2.24226 \\
\hline \multirow[t]{4}{*}{$\begin{array}{l}\text { COMMUNICATION } \\
\text { SKILL }\end{array}$} & 2 & 124 & 15.25 & 2.35343 \\
\hline & 3 & 60 & 17.1833 & 2.02937 \\
\hline & Total & 231 & 15.8658 & 2.38368 \\
\hline & 1 & 47 & 17.7234 & 0.68214 \\
\hline \multirow[t]{3}{*}{ WORK ENVIRONMENT } & 2 & 124 & 17.8548 & 1.47441 \\
\hline & 3 & 60 & 18.25 & 0.75071 \\
\hline & Total & 231 & 17.9307 & 1.19944 \\
\hline
\end{tabular}


Table 4: ANOVA comparing group mean values

\begin{tabular}{|c|c|c|c|c|c|c|}
\hline & & $\begin{array}{l}\text { Sum of } \\
\text { SQR }\end{array}$ & DF & Mean SQR & $\mathbf{F}$ & Sig. \\
\hline \multirow{2}{*}{ LEADERSHIP ROLE } & $\begin{array}{l}\text { Between } \\
\text { Groups }\end{array}$ & 217.366 & 2 & 108.683 & $98.304 *$ & \multirow{2}{*}{0.0} \\
\hline & $\begin{array}{l}\text { Within } \\
\text { Groups }\end{array}$ & 252.072 & 228 & 1.106 & & \\
\hline \multirow{4}{*}{ STAFF MOTIVATION } & Total & 469.437 & 230 & & & \multirow{4}{*}{0.0} \\
\hline & $\begin{array}{l}\text { Between } \\
\text { Groups }\end{array}$ & 157.32 & 2 & 78.66 & $103.172 *$ & \\
\hline & $\begin{array}{l}\text { Within } \\
\text { Groups }\end{array}$ & 173.831 & 228 & 0.762 & & \\
\hline & Total & 331.152 & 230 & & & \\
\hline \multirow[b]{2}{*}{$\begin{array}{l}\text { COMMUNICATION } \\
\text { SKILL }\end{array}$} & $\begin{array}{l}\text { Between } \\
\text { Groups }\end{array}$ & 151.33 & 2 & 75.665 & $14.930 *$ & \multirow[b]{2}{*}{0.0} \\
\hline & $\begin{array}{l}\text { Within } \\
\text { Groups }\end{array}$ & 1155.51 & 228 & 5.068 & & \\
\hline \multirow{4}{*}{ WORK ENVIRONMENT } & Total & 1306.84 & 230 & & & \multirow{4}{*}{0.045} \\
\hline & $\begin{array}{l}\text { Between } \\
\text { Groups }\end{array}$ & 8.85 & 2 & 4.425 & $3.133^{*}$ & \\
\hline & $\begin{array}{l}\text { Within } \\
\text { Groups }\end{array}$ & 322.041 & 228 & 1.412 & & \\
\hline & Total & 330.892 & 230 & & & \\
\hline
\end{tabular}

Table 3 shows the sizes, means and SD for the three groups of respondents based on the levels of their ages. The actual results of ANOVA that compared the five group mean values are shown in Table 4. The comparison yielded F-ratios of 98.304, 103.172, 14.930, and 3.133 for Leadership role, Staff motivation, Communication skill, and Work environment respectively. All the F-ratios are each higher than the critical F-ratio of 3.02 at .05 levels of significance, with 2 and 228 degrees of freedom. With these results, the null hypothesis is rejected for each of the five instances of leadership role, staff motivation, communication skill and work environment. This implies that there is a significant and positive relationship between librarian's educational qualification and their administrative effectiveness in the four aspects of administration which are leadership role, staff motivation, communication skill, librarians' capacity to work with their staff and work environment.

In order to understand the pattern of the significant influence of administrative effectiveness of librarians on leadership role, staff motivation, communication skill librarians' capacity to work with their staff and work environment, a post hoc multiple comparison analysis was carried out using Fisher's least significant difference (LSD) test.

The result of the analysis in Table 5 shows that respondents whose educational qualification is first degree are significantly different in their administrative effectiveness from librarians whose educational qualification is either 
Master's degree or Ph.D and vice versa. In other words, the result shows that the higher the qualification of a librarian the better his or her administrative effectiveness.

Table 5: Fishers' Least Significant Difference (LSD) multiple comparison analysis of the influence of educational qualification on administrative effectiveness of librarians.

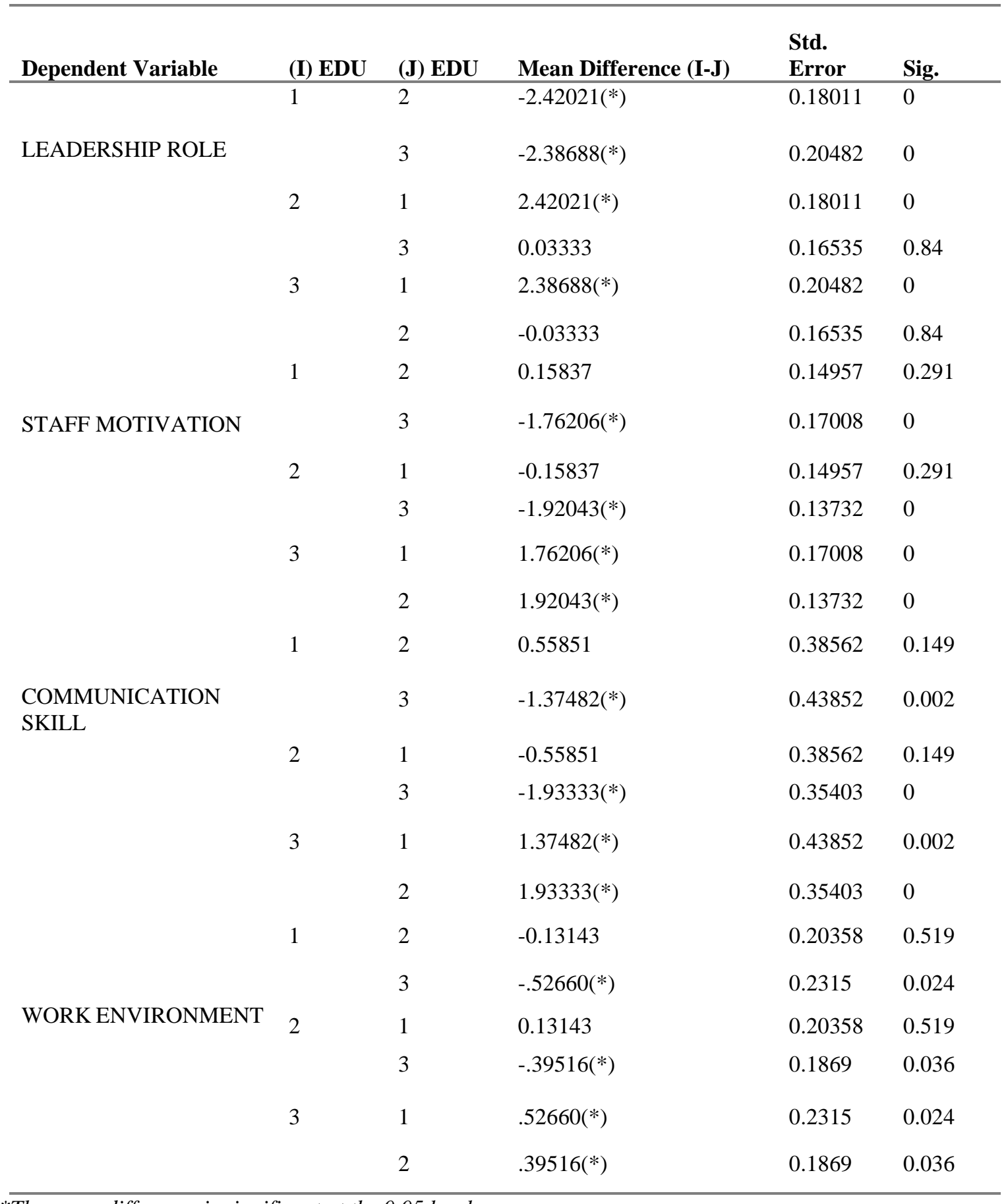

*The mean difference is significant at the 0.05 level. 


\section{TEST OF HYPOTHESIS TWO}

Gender has no significant influence on administrative effectiveness of librarians. The independent variable in this hypothesis is gender (Male and female); while; the dependent variable is an administrative effectiveness of librarians. To test this hypothesis, administrative effectiveness of librarians of male and female were compared using Independent t-test analysis. The result of the analysis is presented in Table 5.

The result of the analysis in Table 6 below reveals that the calculated t-values for Leadership role (5.118) Staff motivation (1.987), Communication skill (4.495) and Work environment (4.744) are respectively higher than the critical t-value of 1.96 at .05 level of significance with 229 degrees of freedom. Therefore, the null hypothesis (is of no significance) is rejected. This implies that sex significantly influence administrative effectiveness of librarians in terms of the four sub-categories.

Table 6: Independent t-test analysis of the influence of gender on administrative effectiveness of librarians ( $\mathrm{N}=231)$

\begin{tabular}{|c|c|c|c|c|c|}
\hline & GENDER & $\mathbf{N}$ & Mean & Std. Deviation & t-value \\
\hline \multirow[t]{2}{*}{ LEADERSHIP ROLE } & 1 & 129 & 19.155 & 1.22761 & \multirow[b]{2}{*}{$5.118 *$} \\
\hline & 2 & 102 & 18.2353 & 1.50364 & \\
\hline \multirow[t]{2}{*}{ STAFF MOTIVATION } & 1 & 129 & 18.2636 & 1.0118 & \multirow[t]{2}{*}{-1.987} \\
\hline & 2 & 102 & 18.5588 & 1.39002 & \\
\hline \multirow[t]{2}{*}{$\begin{array}{l}\text { COMMUNICATION } \\
\text { SKILL }\end{array}$} & 1 & 129 & 15.2636 & 2.50162 & \multirow[t]{2}{*}{$-4.495 *$} \\
\hline & 2 & 102 & 16.6275 & 1.98968 & \\
\hline \multirow[t]{2}{*}{$\begin{array}{l}\text { WORK } \\
\text { ENVIRONMENT }\end{array}$} & 1 & 129 & 17.6124 & 1.39927 & \multirow[t]{2}{*}{-4.744} \\
\hline & 2 & 102 & 18.3333 & 0.70827 & \\
\hline
\end{tabular}

\section{CONCLUSION}

The study has investigated the effect of gender and educational qualification on administrative effectiveness of librarians in south-south Nigeria. The results revealed that educational qualification has a positive influence on the administrative effectiveness of librarians in teams of leadership role, staff motivation, communication skills, and work capability of librarians in South-South Nigeria. Gender was a significant predictor of administrative effectiveness of librarians. The results of this study have practical implications for the practice of librarianship in the sense that, it is hugely essential that library workers are allowed to improve themselves via acquiring postgraduate qualifications such as a master's degree and $\mathrm{PhD}$. Additionally, the management of libraries should always organize seminars, workshops and sponsor staff for further learning and training as this will go a long way to add value to them and improved their skills.

Based on the limited coverage of the study, other researchers who may want to replicate the study should attempt to increase increase the scope to accommodate more sample size. 


\section{REFERENCES}

Aguh, E. C. (2003). Principals' personal characteristics and administration of secondary schools in Rivers State. Unpublished master's thesis, University of Port Harcourt.

Allen, A. A. (2015). Effective school management and supervision: Imperative for quality education service delivery. An International Multidisciplinary Journal Ethiopia, 9(3), 62-74.

Amimaka, I. B. \& Ssemugenyi, F. (2013). Gender \& Work Productivity of Academic Staff in Selected Private Universities in Kampak City, Uganda, International Journal of Research in Business Management, 1: 29-36.

Asif, Raozan, Maliku, Yooums, Uzma and Tahumulla (2012). Gender Comparison of the Pakhtunkhwa. International Journal of Human Resources Studies, 2(3), 2162-3058

Dadzie, P. S. (2005). Information literacy: Assessing the readiness of Ghanaian universities. Information Development, 23(4), 265-277.

Daresh, K. J. and Males, I. R. (2000). Effect of teachers' age and gender on students' perception. Georgia: EDRS Books.

Ebong, P. (2003). The relationship between years spent in education and productivity in South-South, Nigeria. West African Journal of Research and Development in Education, 10(1), 71-86.

Elem, O. (2013). Estimating the effect of teachers pay on pupil attainment using boundary discontinuities. Institution for Fiscal Studies Working paper W14/03, March 2013.

Fadekemi, F.O. \& Isaac, A. A. (2011). Role expectations, the actual role performance and administrative effectiveness of academic staff of South West Universities in Nigeria. European Journal of Educational Studies, 3(1), 181188.

Kumar M (2009). Academic libraries in electronic environment: Paradigm shift. A paper presented at the International Conference on Academic Libraries (ICAL) held at the University of Delhi, India, p. 105.

Lawal, O. O. (1983). Professional education for librarian: International Perspective. Ibadan: Spectrum Books/Jersey UK. p.213.

Lawal, O. O. (2006). Lecture notes on library management (unpublished) University of Calabar.

Madunagu, B. E. (2010). The Nigerian Feminist Movement: Lessons from women in Nigeria.

Obi, F. B. (2020). Investiture speech as the $11^{\text {th }}$ Vice-Chancellor of the University of Calabar, Calabar, December $1^{\text {st }}$

Ogbaji, A. C. and Oti, C. U. (2006). Performance based leadership education: An appraisal and criticism of its concept and operation. Education Leadership, 61(7), 48-52.

Ogunyimi, (2005). Social and political contexts of educational administration. Nsukka: Chuka Educational Publishers.

Okendu, J. N. (2009). Professional development of principals in secondary schools. Institute of Educational Journal, 20(1), 222-224

Okpe (2010). Demographic variables and school climate on principal's job performance in public secondary schools. North East.

Olaleye, F.O. (2001). Sex difference of principals and their effectiveness in school-community relations as perceived by teachers. African Journal of Educational Research, 7(2), 161-176. 
Owolabi. O. T. and Adedayo, J. O. (2012). Effect of teacher's qualification in the performance of senior secondary school physics students. Implication in Technology in Nigeria www.ccseret.org/elt, 5(6), 72.

Saduwa, P. (2011). The new woman. The Nation Newspaper, P. 48.

Sidho, K. S. (2002). School organization and administration. New Delhi: Sterling Publishing Limited.

Uko, E. S. (2002). Gender, leadership styles and administrative effectiveness of principals in Cross Rivers State. Global Journal of Educational Research, 1(1), 1-8.

Wagbara, P.E. (2007). Gender factors and the administrative performance of principals of secondary schools in Rivers State (Unpublished M.Ed thesis) University of Port Harcourt. 